\title{
Japan bids to catch up on gene sequencing
}

[TOKYO] Japan is increasing its effort to develop new technologies in functional genomics, the interpretation of the function of the DNA sequence. It hopes to compete with US and European companies in discovering and patenting human genes.

These projects are in line with the government's recent efforts to commercialize biotechnology research, in particular the new programme aimed at expanding Japan's biotechnology market 25-fold by 2010 (see Nature 397, 554; 1999).

But the move also reflects a sense of urgency among researchers that Japan's genome sequencing projects are lagging significantly behind those of the United States and Britain.

The past month has seen a substantial expansion in the number of projects aimed at developing techniques to study DNA function on a genomic scale. These include a joint venture by Tokyo University and 12 Japanese companies to sequence and analyse full-length human complementary DNA (cDNA), in search of genes that will contribute to the understanding of diseases (see Nature 398, 644; 1999).

DNA microarray, or 'chip' technology, which allows monitoring of gene expression and detection of mutations, is another area which is rapidly expanding in Japan.

Takara Shuzo, a major distiller of shochu (spirits) and a biotechnology company, is planning to commercialize the first domestically produced DNA chip by next March. Leading genome researchers, such as Kenichi Matsubara from the International Institute for Advanced Studies, recently set up a

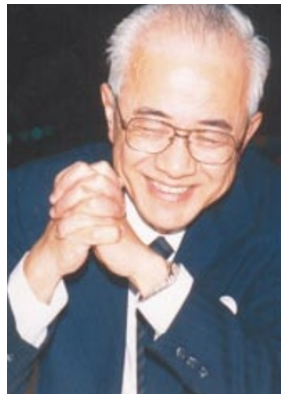

Wada: budget system prevents fast response. new venture business based on such technology.

With technological help from the US biotechnology company Genetic Micro Systems, Takara has made chips programmed with cyanobacterium (Synechococcus) DNA sequenced by Kazusa DNA Research Centre, an institute dedicated to sequencing and analysing DNA. Other companies, such as Takeda Chemical Industries, are developing DNA chip technology to detect mutations in genes that foster a disposition towards cancer.

These moves take place at a time when Japanese partners in the Human Genome Project, which accounts for five to seven per cent of the total effort, are struggling to meet their target of sequencing 10 per cent of the entire human genome. This has become harder since the US and UK research groups accelerated work in response to the challenge posed by Celera Genomics, the US company set up by geneticist J. Craig Venter.

Japan's limited sequencing capacity was highlighted last month when it was revealed that Celera was planning to sequence the entire rice genome in just six weeks. Japanese researchers were planning to complete the sequencing work in ten years using government funding (see Nature 398, 545; 1999).

Japanese researchers are speeding up, for example by improving their sequencing

\section{Drug company backs Africa's war on AIDS}

[WASHINGTON] A leading maker of AIDS drugs announced last week a major donation to fight the disease in southern Africa. The \$18.3 billion company, Bristol-Myers Squibb (BMS), will give $\$ 100$ million over the next five years to a programme of clinical research, physician training and AIDS education, prevention and treatment.

The countries involved are South Africa, Botswana, Namibia, Lesotho and Swaziland, where HIV infection rates in adults are as high as 25 per cent. Most of the work will target women and children. "We feel a moral obligation to take action against this grave situation," says Charles Heimbold, BMS's chairman and chief executive officer.

According to a report in The Wall Street Journal, Heimbold began promoting the idea after a dinner-party conversation last year with Kofi Annan, the United Nations secretary general. Some argue that more than altruism is involved: the move comes as governments in Africa and elsewhere are threatening to ignore patents on expensive AIDS drugs, including several made by BMS.

Later this month, the World Health Assembly, the governing body of the World Health Organisation, will vote on a new policy that may encourage third-world governments to override AIDS drug patents and license home-based companies to make cheap generic versions.

"There's certainly an awareness on the part of companies like Bristol-Myers Squibb that they are vulnerable to criticism on the pricing issue," says Daniel Zingale, the executive director of AIDS Action, a Washington-based lobbying group. Still, he says, the BMS action is "courageous".

But Mark Ahn, BMS's senior director of operations and planning, who is team leader on the Africa project, denies that intellectual property issues play a role. "We felt it was a moral imperative," he says. Meredith Wadman capability and adopting a new strategy focusing on the gene-rich portion of the genome. But funding for new sequencers will not be available for two years because of the sluggish budget system in Japan.

Akiyoshi Wada, director of the Genomic Science Centre (GSC) — set up last October by the Institute of Physical and Chemical Research — says it would be difficult for Japan to bring forward its sequencing deadline, as Britain's Wellcome Trust and the US National Human Genome Research Institute did with the Human Genome Project.

"One of the main problems is how the current budget system restricts projects from receiving extra funds without going through lengthy and convoluted review processes," says Wada. "The second problem is that research directors do not have enough enforcing power to make important policy decisions - let alone drastic ones.”

Many blame Japan's poor track record in genome sequencing on the government's failure to tackle genome research in a coordinated way. In the past, such efforts in Japan have been rather disorderly, with ministries carrying out individual genome projects.

According to Wada, Japan has been effectively excluded from international moves in human genome research, including a decision by the Wellcome Trust and leading international pharmaceutical companies to create a consortium to map singlenucleotide polymorphisms (see Nature 398, 545-546). The reason, he says, was Japan's lack of a flagship genome research centre until GSC was launched last year.

"Many researchers have been long aware of the need to build a large centre for genome research, but it took a while to convince both the government and the scientific community to recognize its importance," says Yoshiyuki Sakaki, leader of GSC's human genome research group and a professor at Tokyo University's Institute of Medical Sciences.

GSC focuses on DNA sequencing, functional genomics and the analysis of protein structure and function. It plans to increase its current sequencing capacity of 1,000 megabases per year by three- to fivefold when its new facilities are completed next October.

"We are hoping that Japan will be able to take an active role in post-sequencing research, including the study on variations in human populations," says Sakaki.

Wada emphasizes the significance of a publicly funded genome sequencing effort, and says that GSC will strongly support the policy followed by the UK and US research groups. "The sequence data should be freely and publicly available to the international research community, and we hope to take part in whatever can be done as publicly funded endeavour."

AsakoSaegusa 